\title{
Strong $\mathrm{CO}_{2}$ emissions from the Arabian Sea during South-West Monsoon
}

\author{
Arne Körtzinger, and Jan C. Duinker \\ Department of Marine Chemistry, Institute for Marine Research at Kiel University, Kiel, Germany \\ Ludger Mintrop \\ Department of Geosciences, University of Bremen, Bremen, Germany
}

\begin{abstract}
The partial pressure of $\mathrm{CO}_{2}\left(p \mathrm{CO}_{2}\right)$ was measured during the 1995 South-West Monsoon in the Arabian Sea. The Arabian Sea was characterized throughout by a moderate supersaturation of 12-30 $\mu \mathrm{atm}$. The stable atmospheric $p \mathrm{CO}_{2}$ level was around $345 \mu \mathrm{atm}$. An extreme supersaturation was found in areas of coastal upwelling off the Omani coast with $p \mathrm{CO}_{2}$ peak values in surface waters of $750 \mu \mathrm{atm}$. Such two-fold saturation (218\%) is rarely found elsewhere in open ocean environments. We also encountered cold upwelled water $300 \mathrm{~nm}$ off the Omani coast in the region of Ekman pumping, which was also characterized by a strongly elevated seawater $p \mathrm{CO}_{2}$ of up to $525 \mu \mathrm{atm}$. Due to the strong monsoonal wind forcing the Arabian Sea as a whole and the areas of upwelling in particular represent a significant source of atmospheric $\mathrm{CO}_{2}$ with flux densities from around $2 \mathrm{mmol} \mathrm{m}^{-2} \mathrm{~d}^{-1}$ in the open ocean to 119 mmol m $\mathrm{m}^{-2} \mathrm{~d}^{-1}$ in coastal upwelling. Local air masses passing the area of coastal upwelling showed increasing $\mathrm{CO}_{2}$ concentrations, which are consistent with such strong emissions.
\end{abstract}

\section{Introduction}

The Arabian Sea is known for its marked seasonality, which is among the most pronounced to be found in the world ocean [Banse and English, 1994]. The monsoonal forcing is the key in the understanding of the strong seasonal oscillations, which are most obvious in the complete semi-annual reversal of the Somali Current [Schott et al., 1990]. A characteristic feature of the South-West Monsoon period (June-September) is the occurrence of intense coastal upwelling off the coasts of Somalia and Oman [Smith and Bottero, 1977; Swallow, 1984; Elliott and Savidge, 1990]. The existence of open-ocean upwelling through Ekman pumping caused by the low-level Findlater Jet [Findlater, 1969] in an area off the Omani coast has also been postulated [Smith and Bottero, 1977].

The man-made perturbation of the global carbon cycle and its oceanic components have been receiving special attention among scientists in recent years [Siegenthaler and Sarmiento, 1993]. A key parameter in this context is the partial pressure of $\mathrm{CO}_{2}\left(p \mathrm{CO}_{2}\right)$ as it provides insight in the saturation state of seawater. Any partial pressure difference $\left(\Delta p \mathrm{CO}_{2}\right)$ between surface seawater and overlying air is the thermodynamic driving force for net $\mathrm{CO}_{2}$ exchange. Few measurements of the $p \mathrm{CO}_{2}$ have been made in the Arabian Sea, especially during the period of the South-West Monsoon [e.g. Miyake and

Copyright 1997 by the American Geophysical Union.

Paper number 97GL01775.

0094-8534/97/97GL-01775\$05.00
Sugimura, 1969; Poisson et al. 1993]. In spite of the limited data base the Arabian Sea appears to serve as a significant source of $\mathrm{CO}_{2}$ to the atmosphere [Somasundar et al., 1990; George et al., 1994]. Three reasons support the assumption of strong $\mathrm{CO}_{2}$ emissions during the South-West Monsoon: First, upwelling caused by the monsoon exposes water with higher $p \mathrm{CO}_{2}$ to the atmosphere as this parameter generally shows an increase with depth. Secondly, this effect is enhanced by the prevailance of an oxygen minimum zone at depths of 100 $1200 \mathrm{~m}$ [Olson et al., 1993; Warren, 1994]. This suboxic layer of accumulated respiratory $\mathrm{CO}_{2}$, resulting in very high $p \mathrm{CO}_{2}$ values, is most pronounced in the Northwest Arabian Sea, where it coincides with the typical source depth and area of the upwelling. Finally, any supersaturated waters exposed to the atmosphere are subject to the strong monsoonal wind forcing, which translates to high transfer coefficents driving large sea-to-air fluxes of $\mathrm{CO}_{2}$.

\section{Methods}

This work was carried out on board the German R/V Meteor (leg 32-5) during the South-West Monsoon in July/August 1995 under the framework of the German JGOFS - Arabian Sea Process Study. The $p \mathrm{CO}_{2}$ in surface seawater and air was measured continuously during the entire cruise from Mahé (Seychelles) to Muscat (Oman). The location of the $\mathrm{pCO}_{2}$ sections discussed below is shown by the letters " $A$ " to " $F$ " in Fig. 1. The newly designed underway $p \mathrm{CO}_{2}$ system has shown excellent agreement with another system during a short at-sea intercomparison [Körtzinger et al., 1996b]. It also took part in the first large international at-sea intercomparison of underway $p \mathrm{CO}_{2}$ systems during a recent Meteor cruise [Körtzinger et al., 1996a].

Seawater $p \mathrm{CO}_{2}$ was logged as 1 -min averages; atmospheric $p \mathrm{CO}_{2}$ was measured every hour. The infrared gas analyzer was calibrated every six hours using a zero gas $\left(\mathrm{CO}_{2}\right.$-free air $)$ and two standard gases containing $\mathrm{CO}_{2}$ in natural air (340.7 and $389.9 \mathrm{ppmv}$ ). The accuracy of $\mathrm{CO}_{2}$ measurements deteriorates from better than \pm 1 ppmv (at 300-450 ppmv) to about \pm 5 ppmv (at $750 \mathrm{ppmv}$ ) due to the restricted concentration range of the calibration gases. Bubble-free seawater was pumped from the "moon pool" of the vessel with a submersible pump. About $2 \mathrm{dm}^{3} \mathrm{~min}^{-1}$ were teed-off close to the equilibrator from the total flow of $40 \mathrm{dm}^{3} \mathrm{~min}^{-1}$. Clean air was sampled above the bridge and pumped to the system at a flow rate of $1 \mathrm{dm}^{3}$ $\min ^{-1}$. All $p \mathrm{CO}_{2}$ data are calculated for $100 \%$ humidity at the air-sea interface. Seawater $p \mathrm{CO}_{2}$ was corrected back to in-situ (bulk) seawater temperature accounting for the slight warming 


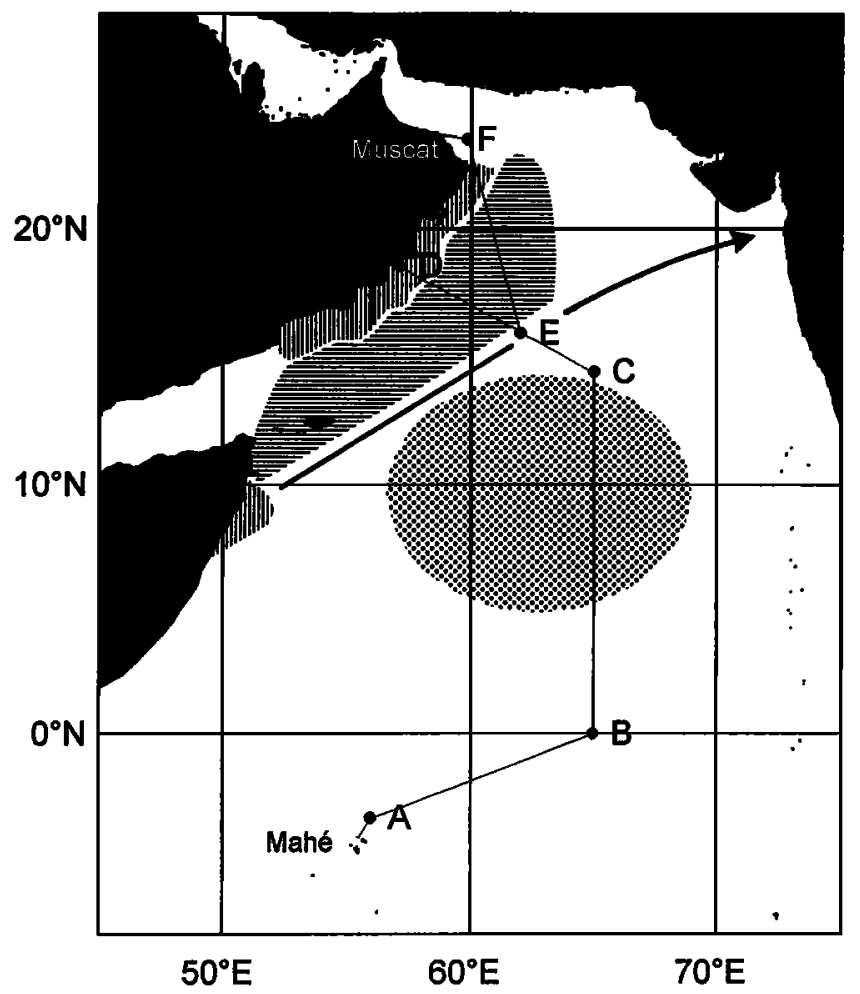

Figure 1. Cruise track of R/V Meteor cruise 32-5 in July/August 1995. The location of surface profiles discussed here is indicated by letters "A" to "F". Also shown are the prominent features of the South-West Monsoon: areas of coastal upwelling off the coasts of Somalia and Oman (vertical hatching), area of Ekman pumping (horizontal hatching), and area of mixed layer deepening (shaded). The arrow delineates the axis of the Findlater Jet.

of about $0.4 \pm 0.1^{\circ} \mathrm{C}$ between the intake and the equilibrator. $I n$ situ temperature and salinity of surface water were measured continuously with the shipborne thermosalinograph. All corrections and equations involved in the calculation of final $p \mathrm{CO}_{2}$ data are more fully described in Körtzinger et al. [1996b]. The oscillations of about $\pm 0.6 \mu \mathrm{atm}$ due to the semidiurnal atmospheric tide in low latitudes (amplitude 1.5-2 mbar) where removed from the atmospheric $p \mathrm{CO}_{2}$ profiles using a sine function fitted to the $p \mathrm{CO}_{2}$ anomalies (measured values minus daily means) based on local time.

\section{Results and Discussion}

Surface $p \mathrm{CO}_{2}$ profiles were classified into two groups. The first (Fig. 2) includes profiles A-B and B-C representing a mainly oligotrophic tropical ocean situation. Surface waters are moderately supersaturated by $12-30 \mu$ atm mainly as a result of the general warming. No typical North-East Trade Wind regime is active in the Indian Ocean. Therefore no equatorial upwelling occurs, which could drive the exposure of waters more strongly supersaturated than those found here. Profile A$B$ can be regarded as being composed of two different patterns separated by a frontal system at $61^{\circ} \mathrm{E}$. Higher temperatures of $28.5-29^{\circ} \mathrm{C}$ to the east of the front are associated with the lowest supersaturation encountered during the entire cruise $\left(\Delta p \mathrm{CO}_{2}=12-15 \mu \mathrm{atm}\right)$. To the west seawater temperatures gradually decrease towards $26.5^{\circ} \mathrm{C}$ with stronger supersaturation $\left(\Delta p \mathrm{CO}_{2}=20-30 \mu \mathrm{atm}\right)$. The front is probably part of the monsoonal convergence zone between the anti-cyclonic gyre with the South-West Monsoon Current to the north and the South Equatorial Current to the south. Another interesting feature can be seen close to the equator at $64^{\circ} 15^{\prime} \mathrm{E}\left(0^{\circ} 20^{\prime} \mathrm{S}\right)$, where the two hemispheres are separated by an atmospheric front across which the $\mathrm{CO}_{2}$ mole fraction in air increases by about $3 \mathrm{ppmv}$ from $\mathrm{S}$ to $\mathrm{N}$, while it is comparatively stable in other areas (except the area of coastal upwelling, see below). Along profile B-C seawater temperature decreases northward, reflecting the deepening of the mixed layer as driven by negative curl wind stress. Although a small parallel trend of about $5 \mu \mathrm{atm}$ increase in $p \mathrm{CO}_{2}(\mathrm{~S}$ to $\mathrm{N}$ ) was observed, the effect of the mixed layer deepening on the degree of $\mathrm{CO}_{2}$ saturation of surface water is weak. However, along section B$\mathrm{C}$ the $\mathrm{pCO}_{2}$ picture generally shows higher small-scale variability, probably as an effect of the prevailing stronger wind stress [Rao et al., 1991] as compared to profile A-B.

The second group of profiles in Fig. 3 shows a drastically different situation. The overall variability of both, $p \mathrm{CO}_{2}$ and temperature is roughly one order of magnitude higher than in Fig. 2 (note extended scales). In profile C-D two prominent features arise from the otherwise moderately supersaturated background situation. The most obvious one is caused by strong coastal upwelling west of $58^{\circ} \mathrm{E}$ with water temperature falling from $>26^{\circ} \mathrm{C}$ to $<20^{\circ} \mathrm{C}$ within $30 \mathrm{~nm}$. Seawater $p \mathrm{CO}_{2}$ rises concurrently to $600-715 \mu \mathrm{atm}$. Such two-fold saturation can be a normal feature in enclosed coastal or estuarine environments [Frankignoulle, 1988], but it is rarely found under oceanic conditions. The second prominent feature is a peak-like cold water structure at $61^{\circ} 15^{\prime} \mathrm{E}$ roughly $300 \mathrm{~nm}$ off the Omani coast, which coincided with a dome-like feature in satellite SST images. The temperature decreases by about 2 $3^{\circ} \mathrm{C}$ towards the center of the peak, $p \mathrm{CO}_{2}$ increased by 100 $150 \mu \mathrm{atm}$. While this feature is situated well in the area of (postulated) Ekman pumping, hydrographical data and its

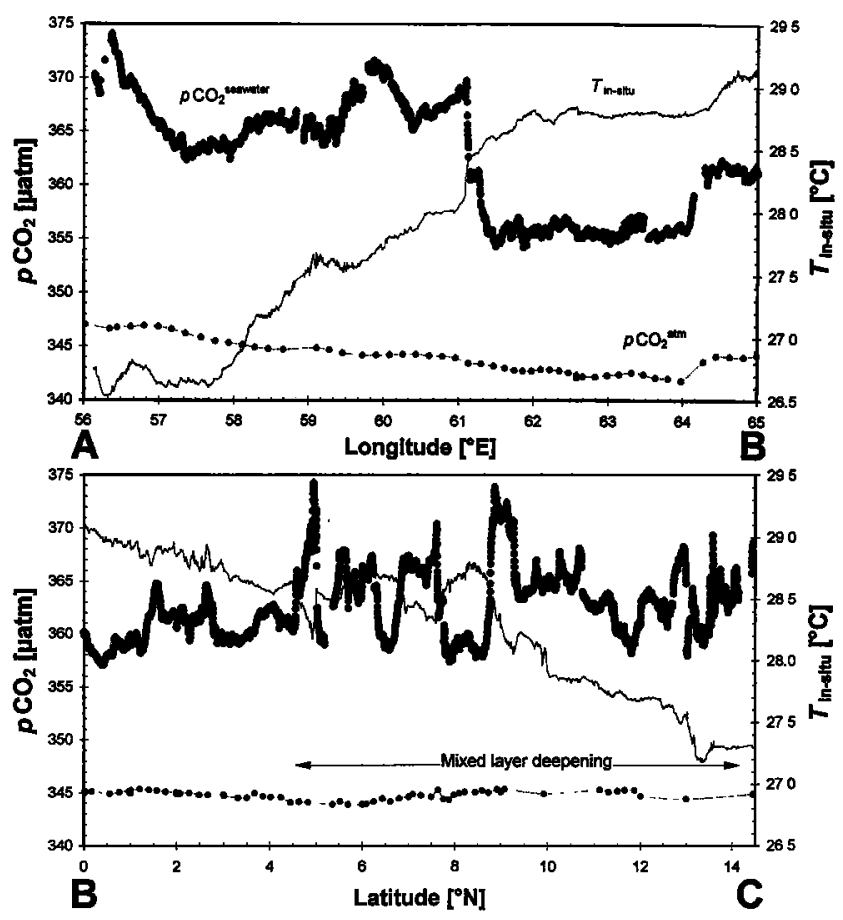

Figure 2. Surface data along sections A-B (top) and B-C (bottom) of R/ Meteor cruise 32-5: the partial pressure of $\mathrm{CO}_{2}\left(p \mathrm{CO}_{2}\right)$ in surface seawater (bold line) and air (dots on dashed line) and the in-situ seawater temperature $T_{\text {in-situ }}$ (thin line). The location of the sections is shown in Fig. 1. 

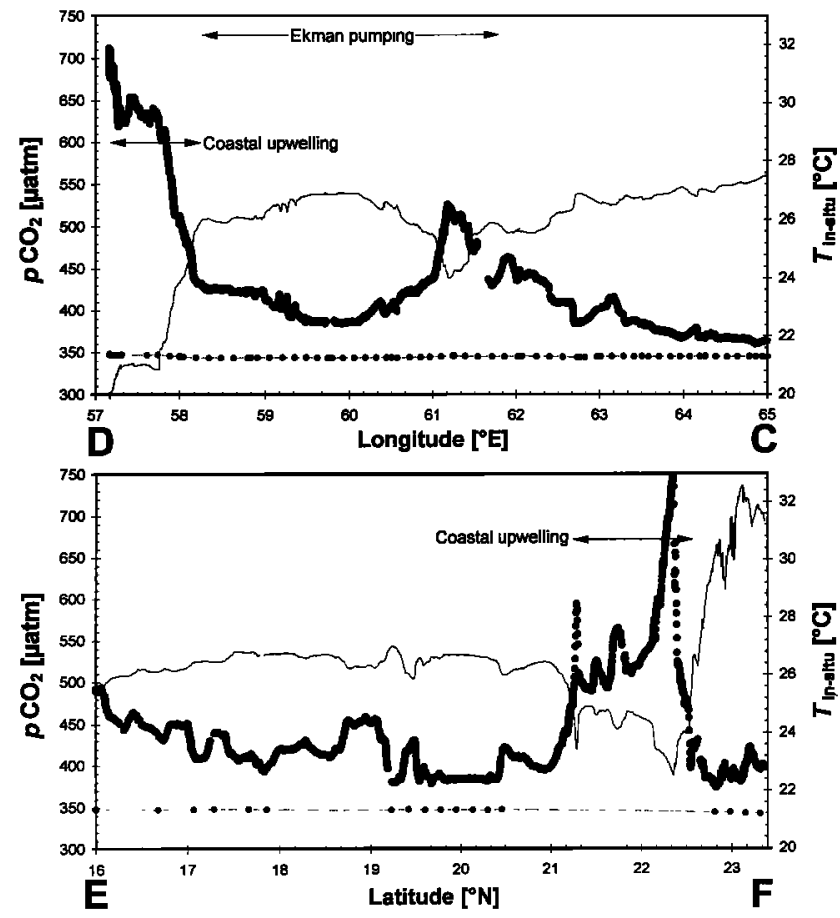

Figure 3. Surface data along sections C-D (top) and E-F (bottom) of $\mathrm{R} / \mathrm{V}$ Meteor cruise 32-5: the partial pressure of $\mathrm{CO}_{2}\left(p \mathrm{CO}_{2}\right)$ in surface seawater (bold line) and air (dots on dashed line) and the in-situ seawater temperature $T_{\text {in-situ }}$ (thin line). The location of the sections is shown in Fig. 1.

dynamic nature do not suggest an origin from the open-ocean upwelling. The feature more likely represents an upwelling filament derived from coastal upwelling off the Omani coast (pers. comm., J. Waniek, Kiel).

Profile E-F crossed the northernmost extension of the coastal upwelling area between $21^{\circ}$ and $22^{\circ} 30^{\prime} \mathrm{N}$. Although the $p \mathrm{CO}_{2}$ and temperature profiles show much stronger small-scale variability than the previous ones, they exhibit similar behaviour. Temperature falls well below $24^{\circ} \mathrm{C}$ in the coastal upwelling region and the $p \mathrm{CO}_{2}$ values are even higher (750 $\mu \mathrm{atm}$ ) with marked peak-like patterns at the flanks. Outside the proper coastal upwelling regime (i.e. $16^{\circ}$ to $21^{\circ} \mathrm{N}$ ) the seawater $p \mathrm{CO}_{2}$ level remains markedly elevated as compared to the situation along sections $A-B$ and $B-C$, yielding $\triangle p \mathrm{CO}_{2}$ values of 30-140 $\mu \mathrm{atm}$. This underlines the important role of the area of Ekman pumping as a $\mathrm{CO}_{2}$ source. Finally, in the Gulf of Oman temperatures exceed $32^{\circ} \mathrm{C}$ and the seawater is supersaturated on the average by about $55 \mu \mathrm{atm}$. This reflects the enhanced warming of surface waters in the gulf. The more pronounced supersaturation in this non-upwelling area is much less subject to strong monsoonal wind forcing and therefore does not generate such extreme emissions.

\section{Air-Sea Exchange of $\mathrm{CO}_{2}$}

The air-sea exchange flux density $\left(F, \mathrm{mmol} \mathrm{m}^{-2} \mathrm{~d}^{-1}\right)$ of $\mathrm{CO}_{2}$ can be expressed as $F=k K^{0}\left(p_{C_{2}}{ }^{\mathrm{sw}}-p \mathrm{CO}_{2}{ }^{\text {air }}\right)$, or $F=k K^{\delta}$ $\left(\Delta p \mathrm{CO}_{2}\right)$, where $k$ is the transfer velocity and $K^{0}$ is the solubility coefficient of $\mathrm{CO}_{2}$ in seawater calculated after Weiss [1974]; $p \mathrm{CO}_{2}{ }^{\mathrm{sw}}$ and $p \mathrm{CO}_{2}$ air are the partial pressures of $\mathrm{CO}_{2}$ in seawater and air, respectively. Their difference is expressed as $\Delta p \mathrm{CO}_{2}$. The valid parametrization of the wind speed dependance of $k$ is still a matter of debate [Watson et al., 1995]. We have used three parametrizations of $k$ which are in common use: the tri-linear relationship after Liss and Merlivat [1986] (hereafter referred to as LM86), the quadratic relationship for climatological winds after Wanninkhof [1992] (hereafter referred to as W92) and the linear relationship of Tans et al. [1990] for $k K^{0}$ (hereafter referred to as T90). The transfer velocities were adjusted to seawater temperatures assuming that $k$ is proportional to $(S c / 600)^{-1 / 2}$ (LM86) or $(S c / 660)^{-1 / 2}$ (W92) at the given wind speeds, where the Schmidt number $S c$ of $\mathrm{CO}_{2}$ was calculated after Wanninkhof [1992].

Based on our results the Arabian Sea serves as a source for atmospheric $\mathrm{CO}_{2}$ throughout. In order to provide a rough estimate of $\mathrm{CO}_{2}$ emissions during the 1995 South-West Monsoon the Arabian Sea was divided into three regimes (Fig. 1): (1) coastal upwelling, (2) Ekman pumping, and (3) open ocean, the areas of which are given in Table 1 . These estimates are based on a synopsis made by J. Brock in SCOR [1995]. Emissions of $\mathrm{CO}_{2}$ were calculated for three months representing the period of the South-West Monsoon using mean observed values of $\Delta p \mathrm{CO}_{2}$, temperature and salinity as well as climatological winds estimated after Rao et al. [1991]. The results are summarized in Table 1 . It should be emphasized that (in contrast to W92 and T90) calculations after LM86 using climatological winds yield too low transfer velocities [Wanninkhof, 1992] and may therefore serve as lower limits.

Flux densities range from $1.6-2.9 \mathrm{mmol} \mathrm{m}^{-2} \mathrm{~d}^{-1}$ in the open ocean to 52-119 mmol m-2 $\mathrm{d}^{-1}$ in the area of coastal upwelling. Combined emissions from areas of coastal upwelling and Ekman pumping (18.5-42.5 $\mathrm{Tg} \mathrm{C}$ ) are of the same order as open ocean emissions (11.2-33.5 $\mathrm{Tg} \mathrm{C}$ ). Total emissions during the 1995 South-West Monsoon (29.6-76.0 $\mathrm{Tg} \mathrm{C}$ ) account for a significant portion of the annual emissions estimated to be $74 \mathrm{Tg} \mathrm{C} \mathrm{yr}^{-1}$ [Somasundar et al., 1990] and 69. $79 \mathrm{Tg} \mathrm{C} \mathrm{yr}^{-1}$ [George et al., 1994]. This proves the importance of the South-West Monsoon which implies that estimates of

Table 1. Estimates of $\mathrm{CO}_{2}$ Emissions from the Arabian Sea during the 1995 South-West Monsoon.

\begin{tabular}{|c|c|c|c|c|c|c|c|}
\hline Regime & $\begin{array}{c}\text { Surface Area } \\
10^{6} \mathrm{~km}^{2}\end{array}$ & $\begin{array}{c}\text { Temperature } \\
{ }^{\circ} \mathrm{C}\end{array}$ & $\begin{array}{c}\text { Wind Speed } \\
\mathrm{m} \mathrm{s}^{-1}\end{array}$ & $\begin{array}{c}\Delta p \mathrm{CO}_{2}^{\mathrm{c}} \\
\mu \mathrm{atm}\end{array}$ & $\begin{array}{c}\text { Emissions } \\
\text { (LM86) }^{\mathrm{d}} \\
\mathrm{Tg} \mathrm{C}\end{array}$ & $\begin{array}{c}\text { Emissions } \\
\text { (W92) }^{d, e} \\
\text { Tg C }\end{array}$ & $\begin{array}{c}\text { Emissions } \\
\text { (T90) }^{\mathrm{d}} \\
\text { Tg C }\end{array}$ \\
\hline $\begin{array}{l}\text { Coastal upwelling } \\
\text { Ekman pumping } \\
\text { Open ocean }\end{array}$ & $\begin{array}{l}0.20 \\
0.50 \\
6.28\end{array}$ & $\begin{array}{l}22 \\
26 \\
28\end{array}$ & $\begin{array}{l}13 \\
13 \\
7.5\end{array}$ & $\begin{array}{c}250 \\
80 \\
25\end{array}$ & $\begin{array}{r}11.2 \\
7.3 \\
11.2\end{array}$ & $\begin{array}{l}25.7 \\
16.7 \\
19.9\end{array}$ & $\begin{array}{l}23.7 \\
18.8 \\
33.5\end{array}$ \\
\hline total & 6.98 & & & & 29.6 & 62.2 & 76.0 \\
\hline
\end{tabular}

a Areas are calculated from an equal-area projection of the Arabian Sea with boundaries of the different regimes after J. Brock in SCOR [1995]. As southem and eastern boundary we have chosen the equator and the southern tip of India. The Gulf of Aden and the Gulf of Oman are included in the calculation. The Persian Gulf and the Red Sea are not .

b Climatological wind speed estimated after Rao et al. [1991].

c Estimates based on measurements during cruise no. 32-5 of R/V Meteor in July/August 1995.

d Emissions $\left(1 \mathrm{Tg}=10^{12} \mathrm{~g}\right.$ ) are calculated for three months, representing the period of the South-West Monsoon.

e Based on the parametrization for climatological winds. 
annual emissions based on premonsoon data tend to be underestimating as already pointed out by George et al. [1994].

A significant increase of atmospheric $\mathrm{CO}_{2}$ concentrations from a mean background value around $359.6 \mathrm{ppmv}$ north of the equator to a mean value of $361.8 \mathrm{ppmv}$ at the northeastern tip of the area of coastal upwelling was observed. This is attributed to strong $\mathrm{CO}_{2}$ emissions into these local air masses during their 24-hour passage across this area. A simple box model calculation was made to check this hypothesis. The box was located on top of the coastal upwelling area with an estimated length $d=1000 \mathrm{~km}$, which is consistent with the area of coastal upwelling as shown in Fig. 1. We assumed a height of the tropospheric boundary layer $H_{\mathrm{m}}=1000 \mathrm{~m}$ (lowlevel Findlater Jet centered at about $1500 \mathrm{~m}$ ) and used a constant wind speed $v=12.5 \mathrm{~m} \mathrm{~s}^{-1}$. The measured background $\mathrm{CO}_{2}$ concentration $\left(C_{1 \mathrm{n}}\right)$ was assigned to the air entering the box from southeast. Measurements at the northeastern tip of the box provided the $\mathrm{CO}_{2}$ concentration of the air leaving the box $\left(C_{\text {out }}\right)$. Vertical exchange through the upper boundary and horizontal exchange by lateral transport were considered to be negligible (i.e. the box was surrounded by background air $\mathrm{CO}_{2}$ concentrations). The flux density $\mathrm{F}$ of $\mathrm{CO}_{2}$ from the ocean into the box is then given by $F=\left(C_{\text {out }}-C_{\mathrm{in}}\right) v H_{\mathrm{m}} d^{-1}=85 \mathrm{mmol}$ $\mathrm{m}^{-2} \mathrm{~d}^{-1}$. This flux density is equivalent to a $\Delta p \mathrm{CO}_{2}$ of 244 $\mu$ atm (W92 for spot winds) to $433 \mu$ atm (LM86) at the observed wind speed. These upper and lower estimates nicely bracket the observed partial pressure difference of 300-400 $\mu$ atm. This admittedly rather crude approximation yields results fully consistent with the presence of an unusual situation, where strong ocean emissions of $\mathrm{CO}_{2}$ directly influence local atmospheric $\mathrm{CO}_{2}$ concentrations.

\section{Summary}

We observed a general moderate supersaturation $\left(\Delta p \mathrm{CO}_{2}=\right.$ $12-30 \mu \mathrm{atm}$ ) of surface waters with respect to atmospheric $\mathrm{CO}_{2}$ concentrations in the Arabian Sea. This situation reflects the tropical characteristics with high water temperatures and is comparable to low latitude areas in the Atlantic and Pacific Oceans. The areas of coastal upwelling and (postulated) Ekman pumping in the northwestern part of the Arabian Sea show a contrasting situation with extreme supersaturation during the period of the South-West Monsoon. The most pronounced supersaturation was found in the area of vigorous coastal upwelling ( $\triangle p \mathrm{CO}_{2}$ up to $405 \mu \mathrm{atm}$ ). This effect is still important in the area of Ekman pumping ( $\triangle p \mathrm{CO}_{2}$ up to $\left.185 \mu \mathrm{atm}\right)$. Emissions during the three month period of the South-West Monsoon are of comparable size in the upwelling regimes and the open ocean although very different surface areas are involved. Total estimated emissions during the 1995 SouthWest Monsoon (29.6-76.0 $\mathrm{Tg} \mathrm{C}$ ) account for a significant portion of literature values of the annual emissions from the Arabian Sea thus underlining the importance of this season. While the calculated $\mathrm{CO}_{2}$ flux density (up to $119 \mathrm{mmol} \mathrm{m}^{-2} \mathrm{~d}^{-1}$ ) is certainly on the high end for oceanic environments the total emissions remain of low significance on the global scale due to the small portion of the world ocean's area involved.

Acknowledgements. We thank the captain and crew of R/V Meteor as well as chief scientist Bernt Zeitzschel for excellent cooperation during cruise 32-5. This work was supported by the German Bundesministerium für Bildung, Wissenschaft, Forschung und Technologie (BMBF) through grant no. 03F0160A.

\section{References}

Banse, K., and D.C. English, Seasonality of coastal zone colour scanner phytoplankton pigment in the offshore oceans, J. Geophys. Res., 99, 7323-7345, 1994.

Elliott, A.J., and G. Savidge, Some features of the upwelling off Oman, J. Mar. Res., 48, 319-333, 1990.

Findlater, J., A major low-level air current near the Indian Ocean during the northern summer, Quart. J. R. Met. Soc., 95, 362-380, 1969.

Frankignoulle, M., Field measurements of air-sea $\mathrm{CO}_{2}$ exchange, Limnol. Oceanogr., 33, 313-322, 1988.

George, M.D., M. Dileep Kumar, S.W.A. Naqvi, S. Banerjee, P.V. Narvekar, S.N. de Sousa, and D.A. Jayakumar, A study of the carbon dioxide system in the northern Indian Ocean during premonsoon, Mar. Chem., 47, 243-254, 1994.

Körtzinger, A., L. Mintrop, and J.C. Duinker, The floating dripstone cave - $\mathrm{CO}_{2}$ teams compare underway systems, U.S. JGOFS News, 7 , 14-15, 1996a.

Körtzinger, A., H. Thomas, B. Schneider, N. Gronau, L. Mintrop, and J.C. Duinker, At-sea intercomparison of two newly designed underway $p \mathrm{CO}_{2}$ systems - Encouraging results. Mar. Chem., 52, 133$145,1996 \mathrm{~b}$.

Liss, P.S., and L. Merlivat, Air-sea exchange rates: Introduction and synthesis, in The Role of Air-Sea Exchange in Geochemical Cycling, edited by P. Buat-Ménard, pp. 113-127, D. Reidel Publishing Company, Dordrecht, 1986.

Miyake, $Y$., and $Y$. Sugimura, Carbon dioxide in the surface waters and the atmosphere in the Pacific, Indian and the Antarctic Ocean areas, Rec. Oceanogr. Works Japan, 10, 28-33, 1969.

Olson, D.B., G.L. Hitchcock, R.A. Fine, and B.A. Warren, Maintenance of the low-oxygen layer in the central Arabian Sea, Deep-Sea Res., 40, 673-685, 1993.

Poisson, A., N. Metzl, C. Brunet, B. Schauer, B. Bres, D. Ruiz-Pino, and F. Louanchi, Variability of sources and sinks of $\mathrm{CO}_{2}$ in the Western Indian and Southern Oceans during the year 1991, J. Geophys. Res., C12, 22,759-22,778, 1993.

Rao, R.R., R.L. Molinari, and J. Festa, Surface Meteorological and Near Surface Oceanographic Atlas of the Tropical Indian Ocean, NOAA Technical Memorandum ERL AOML-69, 1991.

Schott, F., J.C. Swallow, and M. Fieux, The Somali Current at the Equator: annual cycle of currents and transports in the upper 1,000 $\mathrm{m}$ and connection with neighbouring latitudes, Deep-Sea Res., 37, $1825-1848,1990$.

SCOR, The Joint Global Ocean FluxStudy - Arabian Sea Process Study, JGOFS Report No. 17, 64 pp., Baltimore, 1995.

Siegenthaler, U., and J.L. Sarmiento, Atmospheric carbon dioxide and the ocean, Nature, 365, 119-125, 1993.

Smith, R.L., and J.S. Bottero, On upwelling in the Arabian Sea, in $A$ Voyage of Discovery, edited by M.V. Angel, pp. 291-304, Pergamon Press, New York, 1977.

Somasundar, K., A. Rajendran, M. Dileep Kumar, and R. Sen Gupta, Carbon and nitrogen budgets of the Arabian Sea, Mar. Chem., 30 , 363-377, 1990.

Swallow, J.C., Some aspects of the physical oceanography of the Indian Ocean, Deep-Sea. Res., 31, 639-650, 1984.

Tans, P.P., I.Y. Fung, and T. Takahashi, Observational constraints on the global atmospheric $\mathrm{CO}_{2}$ budget, Science, 247, 1431-1438, 1990.

Wanninkhof, R., Relationship between wind speed and gas exchange over the ocean, J. Geophys. Res., 97, 7373-7382, 1992.

Warren, B.A., Context of the suboxic layer in the Arabian Sea, in Biogeochemistry of the Arabian Sea, edited by D. Lal, pp. 203-216, Indian Academy of Sciences, Bangalore, 1994.

Watson, A.J., P.D. Nightingale, and D.J. Cooper, Modelling atmosphereocean $\mathrm{CO}_{2}$ transfer, Phil. Trans. R. Soc. Lond., B, 348, 125-132, 1995.

Weiss, R.F., Carbon dioxide in water and seawater: the solubility of a non-ideal gas, Mar. Chem., 2, 203-215, 1974.

J.C. Duinker, A. Körtzinger, and L. Mintrop, Institute for Marine Research at Kiel University, Department of Marine Chemistry, Düsternbrooker Weg 20, D-24105 Kiel, Germany. (e-mail: akoertzinger@ifm.uni-kiel.de)

(Received January 6, 1997; revised May 22, 1997; accepted May 30, 1997) 